\title{
Gefitinib sensitization of cisplatin-resistant wild-type EGFR non-small cell lung cancer cells
}

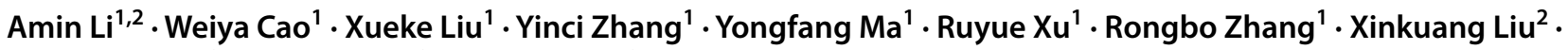 \\ Shuping $\mathrm{Zhou}^{2} \cdot$ Ruikai Wang $^{2} \cdot$ Jiachang $\mathrm{Liu}^{2} \cdot$ Xiaolong Tang $^{1}$
}

Received: 23 February 2020 / Accepted: 18 April 2020 / Published online: 27 April 2020

(c) Springer-Verlag GmbH Germany, part of Springer Nature 2020

\begin{abstract}
Purpose The usual first-line strategy of wild-type EGFR (wtEGFR) non-small cell lung cancer (NSCLC) remains cisplatinbased chemotherapy. However, cisplatin often loses effectiveness because most tumors acquire drug resistance over time. As EGFR is the most important pro-survival/proliferation signal receptor in NSCLC cells, we aimed at investigating whether cisplatin resistance is related to EGFR activation and further evaluating the combined effects of cisplatin/gefitinib (EGFRtyrosine kinase inhibitor, EGFR-TKI) on cisplatin-resistant wtEGFR NSCLC cells.

Materials and methods EGFR activation was analysed in parental and cisplatin-resistant wtEGFR NSCLC cell lines (H358 and $\mathrm{H} 358^{\mathrm{R}}$, A549 and $\mathrm{A} 549^{\mathrm{R}}$ ). Cellular proliferation and apoptosis of $\mathrm{H} 358^{\mathrm{R}} / \mathrm{A} 549^{\mathrm{R}}$ cells treated with cisplatin or gefitinib, alone or in combination were investigated, and the related effector protein was detected by western blot analysis. Anti-tumor effect of two drugs combined was evaluated in animal models of $\mathrm{H} 358^{\mathrm{R}}$ xenografts in vivo.

Results EGFR was significantly phosphorylated in cisplatin-resistant wtEGFR NSCLC cells $H 358^{R}$ and A549R than their parental cells. In $\mathrm{H} 358^{\mathrm{R}}$ and $\mathrm{A} 549^{\mathrm{R}}$ cells, anti-proliferative ability of gefitinib was further improved, and gefitinib combined with cisplatin enhanced inhibition of cellular survive/proliferation, and promotion of apoptosis in vitro. The combined effects were also associated with the inhibition of EGFR downstream effector proteins. Similarly, in vivo, gefitinib and cisplatin in combination significantly inhibited tumor growth of $\mathrm{H} 358^{\mathrm{R}}$ xenografts.

Conclusion Abnormal activation of EGFR may induce wtEGFR NSCLC cell resistance to cisplatin. The combined effects of cisplatin/gefitinib suggest that gefitinib, as a combination therapy for patients with cisplatin-resistant wtEGFR NSCLC should be considered.
\end{abstract}

Keywords Gefitinib $\cdot$ Cisplatin $\cdot$ Resistance $\cdot$ wtEGFR NSCLC

\section{Introduction}

Non-small cell lung cancer (NSCLC) accounts for about $85 \%$ of lung cancers and is the leading cause of cancerrelated deaths worldwide. More than 65\% NSCLC patients

Amin Li, Weiya Cao, Xueke Liu and Yinci Zhang contributed equally to this work.

Xiaolong Tang

txljd2006@126.com

1 Medical School, Anhui University of Science and Technology, 168 Taifeng Street, Tianjiaan District, Huainan 232001, China

2 First Affiliated Hospital, Anhui University of Science and Technology (Huainan First People's Hospital), Huainan 232001, China present with locally advanced or metastatic disease when diagnosed (Reck et al. 2013). Despite much effort was made to find out new therapeutic strategies in NSCLC, cisplatinbased chemotherapy remains the backbone therapy in wildtype EGFR NSCLC (wtEGFR NSCLC). Unfortunately, less than $15 \%$ of patients with lung cancer survive more than 5 years.

The main reason for such low survival rate of wtEGFR NSCLC is that most patients develop resistance after several cycles of cisplatin-based chemotherapy. Researches have discovered the mechanism of cisplatin resistance mainly includes: pre-target resistance (Chen et al. 2012; Kuo et al. 2012; Ishida et al. 2010); on-target resistance (Friboulet et al. 2013; Kamal et al. 2010; Olaussen et al. 2006); posttarget resistance (Goloudina et al. 2012; Motte et al. 2007; 
Michaud et al. 2009) and off-target resistance (Ren et al. 2010; Shen et al. 2010; Yu et al. 2011). The susceptibility of wtEGFR NSCLC cells to cisplatin can be limited by offtarget mechanisms, that is, molecular circuitries that deliver compensatory pro-survival signals even though they are not directly activated by cisplatin (Galluzzi et al. 2012).

EGFR is the most important pro-survival signal receptor for EGF and belongs to tyrosine kinase receptor of wtEGFR NSCLC cells. The abnormal activation of EGFR downstream signal pathways, such as Ras/Raf/MAPK, $\mathrm{PI} 3 \mathrm{~K} / \mathrm{AKT} / \mathrm{mTOR}$, and Jak/stat, induces tumor cells antiapoptosis, proliferation, angiogenesis and drug resistance (Leon et al. 2016). There are reports also revealed a EGFindependent activation of EGFR in epithelial and non-epithelial cells ( $\mathrm{Lu}$ et al. 2014; Hardbower et al. 2016; Guo et al. 2015). Therefore, we wondered whether the off-target resistance of cisplatin is related to ligand-independent activation of EGFR.

If cisplatin resistance is related to EGFR activation, inhibiting EGFR activation should restore the cisplatin sensitivity of cisplatin-resistant wtEGFR NSCLC cells. The commonly used EGFR inhibitor in clinical is EGFR tyrosine kinase inhibitor (EGFR-TKI). Gefitinib, as the first generation of EGFR-TKI, has small side effects and significant anti-tumor activity, especially for EGFR-mutant NSCLC. However, the indication of gefitinib in patients with wtEGFR NSCLC is more debated (Zhao et al. 2014).

In our study, we investigated the activation of EGFR in wtEGFR NSCLC parental cell lines and cisplatin-resistant cell lines, further assessed the effects of gefitinib in combination with cisplatin on cisplatin-resistant cell lines. Our results showed gefitinib restored most sensitivity of cisplatin-resistant wtEGFR NSCLC cells to cisplatin and support the view that EGFR-TKI may become a combined treatment strategy for patients with cisplatin-resistant wtEGFR NSCLC.

\section{Materials and methods}

\section{Cell lines, chemicals and antibodies}

Human wtEGFR NSCLC cell lines H358 and A549 were obtained from American Type Culture Collection (ATCC, Rockville, MD, USA). Cisplatin-resistant cell lines, $\mathrm{H} 358^{\mathrm{R}}$ and $A 549^{R}$, were induced by constant exposure to cisplatin $(2 \mu \mathrm{mol} / \mathrm{L})$ to imitate acquired resistance. Both cell lines were cultured in 10\% FBS-containing medium (RPMI1640,
Gibco, Thermo Fisher Scientific) and maintained in a $5 \% \mathrm{CO}_{2}$ incubator at $37{ }^{\circ} \mathrm{C}$. Cisplatin (A8321) was purchased from APExBIO Technology LLC (Houston, Texas, USA); Gefitinib (ZD1839) was obtained from Med Chem Express (Monmouth, Junction, USA). (3, 4, 5-dimethylthiazol-2-yl)-2,5-diphenyltetrazolium bromide (MTT) and 5,5',6,6'-tetrachloro-1,1',3,3'-tetraethyl-benzimidazolyl carbocyanine iodide JC-1 were provided by Sigma-Aldrich (St. Louis, MO, USA). Antibodies used were following: total EGFR (\#4267), phospho-EGFR (\#3777), Phospho-AKT Antibody Sampler Kit (\#9916), Phospho-Erk1/2 Antibody Sampler Kit (\#9911), Apoptosis Antibody Sampler Kit (\#9915) and other antibody sampler kits were obtained from Cell Signaling Technology (Danvers, MA, USA).

\section{IC50 measurements}

Cells were plated in 96-well plates over night and treated by the indicated drugs for $48 \mathrm{~h}$. Then the cells were incubated with MTT 4 h at $37{ }^{\circ} \mathrm{C}$, formazan cristae were solubilized in dimethyl sulfoxide (DMSO) and optical density (OD) was read at $570 \mathrm{~nm}$. $\mathrm{IC}_{50}$ was calculated as described by Chou and colleagues (Chou 2006).

\section{Phosphorylated EGFR detection}

Flow cytometry was performed for the detection of intracellular phosphorylated EGFR with BD FACSCalibur. Cells were fixed by $4 \%$ paraformaldehyde, permeabilized by $90 \%$ methanol and saturated by $5 \%$ BSA. Followed incubated in the p-EGFR antibody diluted in 1\% BSA and coupled to fluorescent (Alexa Fluor 488) secondary antibody at room temperature. Non-specific binding of secondary antibody was measured by omitting primary antibody and the corresponding mean fluorescence was subtracted from the signal measured with each primary antibody.

\section{Western blot analysis}

Total protein was extracted from cells lysed with radioimmunoprecipitation buffer (RIPA, Beyotime Biotechnology, Shanghai, China) containing a protease inhibitor cocktail (Beyotime Biotechnology, Shanghai, China) and centrifuged. The protein concentration of the supernatant was measured with BCA200 protein assay kit (Biosharp Life Science, Hefei, China) and equalized before loading to the gel. Target proteins were separated by sodium dodecyl sulfate-polyacrylamide gel electrophoresis (SDS-PAGE) and 
electrotransferred onto a polyvinylidene fluoride membrane (Millipore, USA). After blocking with Tris-buffered saline/ Tween 20 containing 5\% fat-free milk, detecting antibodies were applied. Protein bands were visualized with a chemiluminescence detection kit (Thermo), and images were captured with a scanner using Quality One software (Bio-Rad).

\section{Viability assay}

Cells were seeded into 96-well plates and cultured for $24 \mathrm{~h}$ in a $5 \% \mathrm{CO}_{2}$ incubator at $37{ }^{\circ} \mathrm{C}$. Then the cells were treated by the indicated drugs for $48 \mathrm{~h}$. Carrier dimethyl sulfoxide was used as a control. Cell viability was measured with MTT assay in accordance with the manufacturer's instructions. Ten microliters of MTT $(5 \mathrm{mg} / \mathrm{mL})$ were added to each well and incubated for $4 \mathrm{~h}$. After aspiration, $100 \mu \mathrm{l}$ of DMSO were added. Cell proliferation/inhibition rate was calculated with Graphpad Prism Version 5.0 software according to $\mathrm{OD}_{\lambda=570 \mathrm{~nm}}$ by use of a microplate reader (BioRad Model 680; Bio-Rad Laboratories Inc., Hertfordshire, UK).

\section{Clone formation assay}

Cells were seeded in six-well culture plates at a density of 1000 cells per well and cultured for $24 \mathrm{~h}$. The cells were treated with the drugs for another $24 \mathrm{~h}$. Then the medium containing the reagents was removed and replaced with fresh medium. The cells were further cultured for about 10 days until colonies were visible. Colonies were fixed with $4 \%$ paraformaldehyde and stained with $0.1 \%$ (w/v) crystal violet. Cell colonies were counted, and the number cultured with drugs was compared with the control.

\section{Cell-cycle analysis}

The cell cycle was analyzed with flow cytometry. Cells were planted in 12-well plates and incubated for $24 \mathrm{~h}$ followed by treatment with drugs for additional $48 \mathrm{~h}$. The cells were dissociated and fixed with cold $75 \%$ ethanol, then incubated with RNase $(100 \mathrm{ng} / \mathrm{mL})$ and stained with propidium iodide (PI, $50 \mathrm{ng} / \mathrm{mL}$ ). Dye was removed, and the cells were resuspended with PBS for cell-cycle analysis by flow cytometry (BD FACSCalibur, USA).

\section{Apoptosis detection}

Cell apoptosis was analyzed with an Annexin V-FITC/ propidium iodide (PI) staining protocol. Cells were seeded in 24-well plates and incubated for $24 \mathrm{~h}$, followed by drug treatment for an additional $48 \mathrm{~h}$. Cells were collected after digestion and centrifugation, then incubated with Annexin V-FITC/PI at room temperature for $15 \mathrm{~min}$ in the dark. Flow cytometry was performed after cells were incubated with fluorescence staining.

\section{Mitochondrial membrane potential $(\Delta \Psi m)$ measurement}

JC-1 (5,5',6,6'-tetrachloro-1,1',3,3'-tetraethyl-benzimidazolyl carbocyanine iodide) is a sensitive probe for measuring mitochondrial membrane potential (Zhdanov et al. 2017). The high/ low mitochondrial membrane potential of cells treated with dugs determined red/green fluorescence intensity excited by polymer/monomer of JC-1, from which the mitochondrial apoptosis level of the cells was analyzed. After the cells were incubated with drugs for $48 \mathrm{~h}$, they were stained with $10 \mu \mathrm{g} /$ $\mathrm{mL}$ JC-1 for a half hour at room temperature. Fluorescence was visualized by fluorescence microscope.

\section{Animal experiments}

All animal experiments were carried out in accordance with the principles and procedures approved by the Animal Experimental Ethics Committee of Anhui University of Science and Technology. Approximately 5-6 weeks of age female $\mathrm{BALB} / \mathrm{c}$ nude mice were purchased from Nanjing Junke Biotechnology Co. Ltd. $100 \mu \mathrm{H} 358^{\mathrm{R}}$ cell suspension $\left(5 \times 10^{7} / \mathrm{mL}\right)$ was subcutaneously injected into the right shoulders of the mice. When tumors reached a size of about $100 \mathrm{~mm}^{3}$, mice were randomly divided into four groups. The "control" group has no treatment; the "cisplatin" group was treated by cisplatin of intraperitoneal injection at day 0 and day $7(2 \mathrm{mg} / \mathrm{kg})$; the "gefitinib" group was received gefitinib $(150 \mathrm{mg} / \mathrm{kg})$ daily orally by gavage; the "cisplatin/gefitinib" group was treated by both drugs as described above. Tumor volume was measured with a caliper two perpendicular tumor diameters twice a week, and the formula [(length $) \times(\text { width })^{2} / 2$ ] was used to estimate the tumor growth. Body weight was measured to assess systemic toxicity.

\section{Statistical analysis}

All experiments were repeated three times independently and analyzed by Student $t$-test or two-way ANOVA using GraphPad Prism 5 (GraphPad Software, Inc., San Diego, CA, USA). $P<0.05$ was taken as statistically significant. 


\section{Results}

\section{IC50 to cisplatin of H358R and A549R cells}

We induced two cisplatin-resistant wtEGFR NSCLC cell lines, named $\mathrm{H} 358^{\mathrm{R}}$ and $\mathrm{A} 549^{\mathrm{R}}$, derivated from $\mathrm{H} 358$ and A549 cells by continuous treatment with $2 \mu \mathrm{mol} / \mathrm{L}$ cisplatin. Two months later, cells could proliferate and subcultured in the presence of cisplatin. The cell morphology also changes significantly compared to their parental cells (Fig. 1a). To determine their resistance, we measured their $\mathrm{IC}_{50}$ to cisplatin. The $\mathrm{IC}_{50}$ to cisplatin of $\mathrm{H} 358^{\mathrm{R}}$ and $\mathrm{A} 549^{\mathrm{R}}$ cells was $28 \mu \mathrm{M}$ and $25 \mu \mathrm{M}$, respectively (Fig. 1b).

\section{Significant phosphorylation of EGFR and downstream AKT/ERK in $\mathrm{H}_{358^{\mathrm{R}}}$ and $A 549^{\mathrm{R}}$ cells}

To determine whether the resistance to cisplatin of wtEGFR NSCLC cells is related to activation of EGFR, we detected EGFR phosphorylation in $\mathrm{H} 358^{\mathrm{R}}$ and $\mathrm{A} 549^{\mathrm{R}}$ cells using flow cytometry. As shown in Fig. 2a, EGFR phosphorylation was significantly increased compared with their parental H358 and A549 cells. We further detected phosphorylation level of EGFR and its downstream AKT/ERK in $\mathrm{H} 358^{\mathrm{R}}$ and $\mathrm{A} 549^{\mathrm{R}}$ cells, using western blot assay. The results also confirmed that phosphorylation of EGFR and its downstream molecules AKT/ERK in $\mathrm{H} 358^{\mathrm{R}}$ and $\mathrm{A} 549^{\mathrm{R}}$ cells was significantly increased (Fig. 2b), suggesting abnormal activation of EGFR signal in cisplatin-resistant cell lines $\mathrm{H} 358^{\mathrm{R}}$ and $\mathrm{A} 549^{\mathrm{R}}$.

\section{Gefitinib increases inhibition of proliferation in $\mathrm{H}^{358^{\mathrm{R}}}$ and $\mathrm{A} 549^{\mathrm{R}}$ cells}

Gefitinib is an EGFR tyrosine kinase inhibitor that effectively inhibits EGFR phosphorylation and cell survival/ proliferation. To further test whether EGFR phosphorylation is effective in $\mathrm{H} 358^{\mathrm{R}}$ and $\mathrm{A} 549^{\mathrm{R}}$ cells, we measured the proliferation activity of $\mathrm{H} 358^{\mathrm{R}} / \mathrm{A} 549^{\mathrm{R}}$ cells and their parental cells after gefitinib treatment separately by MTT (Fig. 3a) and clone formation assay (Fig. 3b). The results showed that the inhibitory effect of gefitinib on $\mathrm{H} 358^{\mathrm{R}}$ and A54 $9^{R}$ cells is further enhanced, which demonstrated the effective activation of EGFR in $\mathrm{H} 358^{\mathrm{R}}$ and $\mathrm{A} 549^{\mathrm{R}}$ cells at the cytological level.

\section{Gefitinib inhibits EGFR/AKT/ERK phosphorylation in $\mathrm{H}_{358^{\mathrm{R}}}$ and $\mathrm{A} 549^{\mathrm{R}}$ cells}

To determine the minimum concentration of gefitinib inhibiting phosphorylation of EGFR and its downstream molecules AKT/ERK in $\mathrm{H} 358^{\mathrm{R}}$ and $\mathrm{A} 549^{\mathrm{R}}$ cells, we used western blot to detect EGFR/AKT/ERK phosphorylation levels after $48 \mathrm{~h}$ of gefitinib at different intervention concentrations. As shown in Fig. 4a, $5 \mu \mathrm{M}$ gefitinib could simultaneously inhibit EGFR/AKT/ERK phosphorylation in $\mathrm{H} 358^{\mathrm{R}}$ cells. For A $549^{R}$ cells, the minimum concentration of gefitinib inhibiting EGFR/AKT/ERK phosphorylation is $10 \mu \mathrm{M}$ (Fig. $4 \mathrm{~b}$ ). $5 \mu \mathrm{M}$ and $10 \mu \mathrm{M}$ of gefitinib will be used as a subsequent combination concentration.

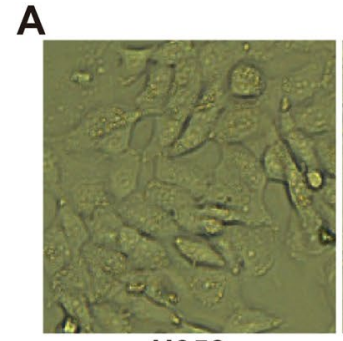

H358

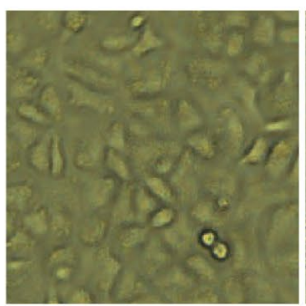

A549

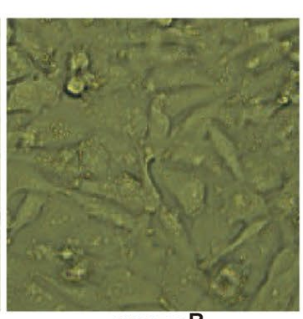

$H 358^{R}$

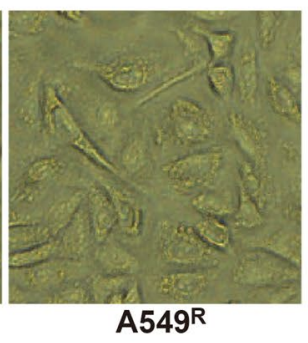

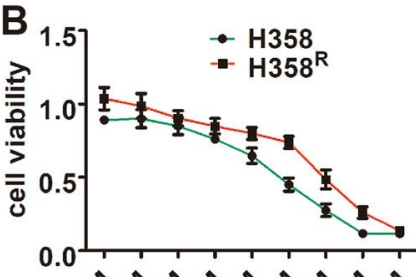

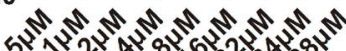

Cisplatin $48 \mathrm{~h}$

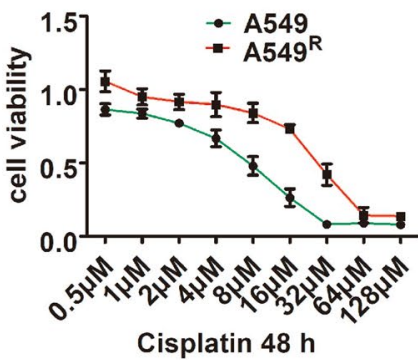

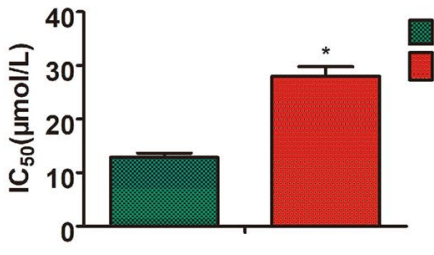

$\mathrm{H} 358(12 \mu \mathrm{M})$

$\mathrm{H} 358^{\mathrm{R}}(28 \mu \mathrm{M})$

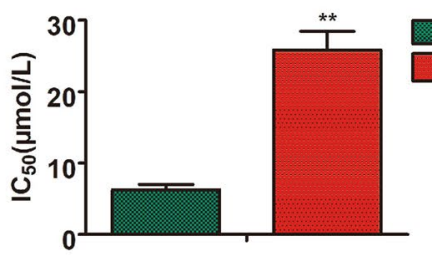

Cisplatin $48 \mathrm{~h}$

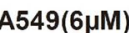

$A 549^{R}(25 \mu \mathrm{M})$
Fig. 1 Morphology and resistance of cisplatin-resistant cell lines $\mathrm{H} 358^{\mathrm{R}}$ and $\mathrm{A} 549^{\mathrm{R}}$. a $\mathrm{H} 358^{\mathrm{R}}$ and $\mathrm{A} 549^{\mathrm{R}}$ cell lines showed irregular long spindles, flat, and blurred borders compared to their parental cell lines. b Cells were treated by a range of increasing cisplatin concentrations for $48 \mathrm{~h}$ and $\mathrm{IC}_{50}$ was calculated as described by Chou and colleagues with MTT assay $\left({ }^{*} P<0.05, * * P<0.01\right)$ 

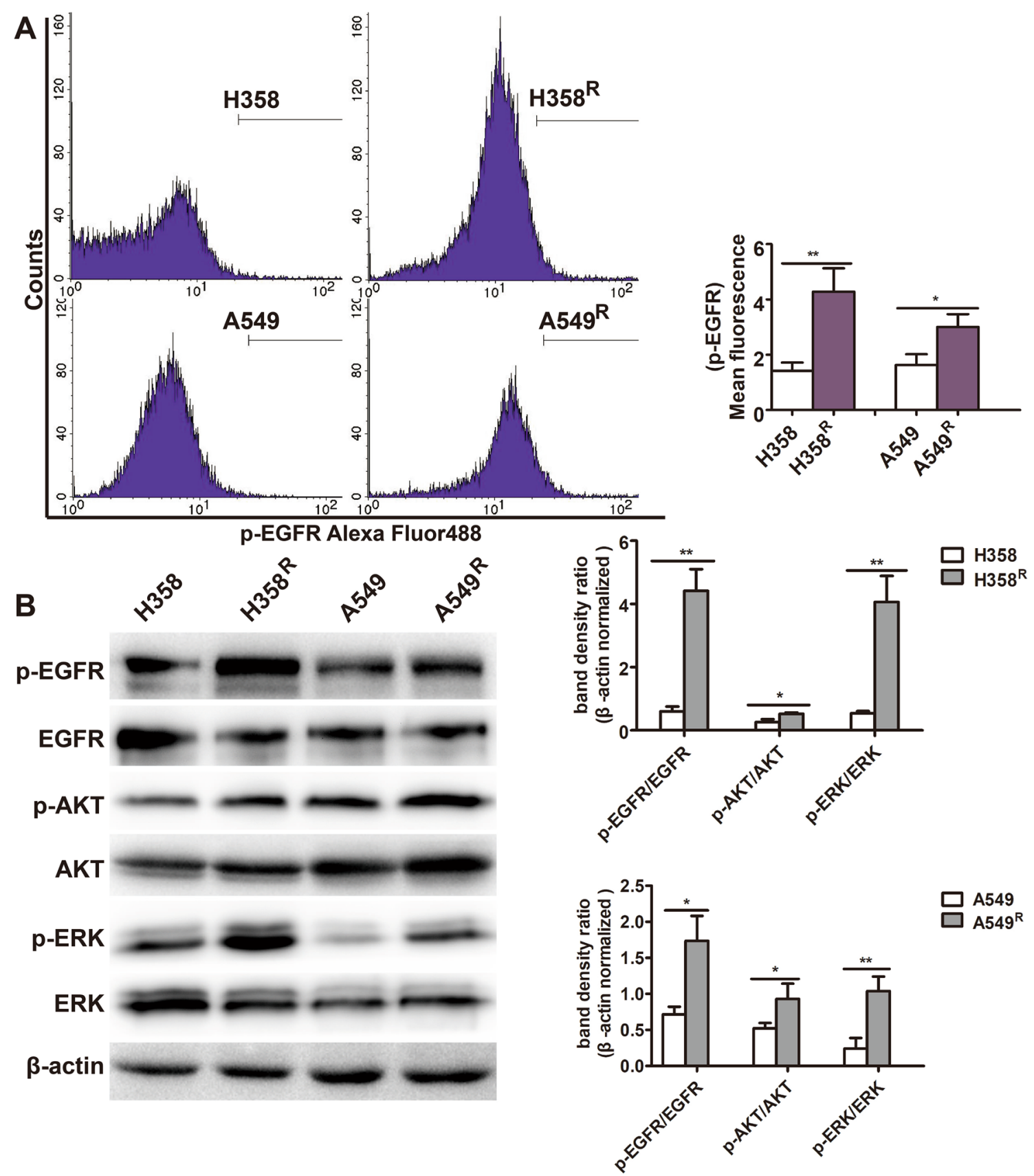

Fig. 2 Significant phosphorylation of EGFR, AKT, ERK in $H 358^{\mathrm{R}}$ and $A 549^{R}$ cell lines. a Cells were fixed and incubated with p-EGFR antibody. Fluorescence was measured by flow cytometry. b Expres-

sion of p-EGFR, p-AKT, p-ERK in $\mathrm{H} 358^{\mathrm{R}}$ and $\mathrm{A} 549^{\mathrm{R}}$ cells by western blotting analysis $(* P<0.05, * * P<0.01)$ 
Fig. 3 Increased sensitivity of $\mathrm{H} 358^{\mathrm{R}}$ and $\mathrm{A} 549^{\mathrm{R}}$ cell lines to gefitinib (GFB). a Cells were treated by a range of increasing gefitinib concentrations for $48 \mathrm{~h}$ and cell viability was calculated by MTT assay. b Cells were incubated with gefitinib (GFB) for $48 \mathrm{~h}$ and the inhibitory effects of gefitinib (GFB) on single cell proliferation in $\mathrm{H} 358^{\mathrm{R}} / \mathrm{A} 549^{\mathrm{R}}$ and their parental cells were assessed by clone formation assay $(* * P<0.01)$
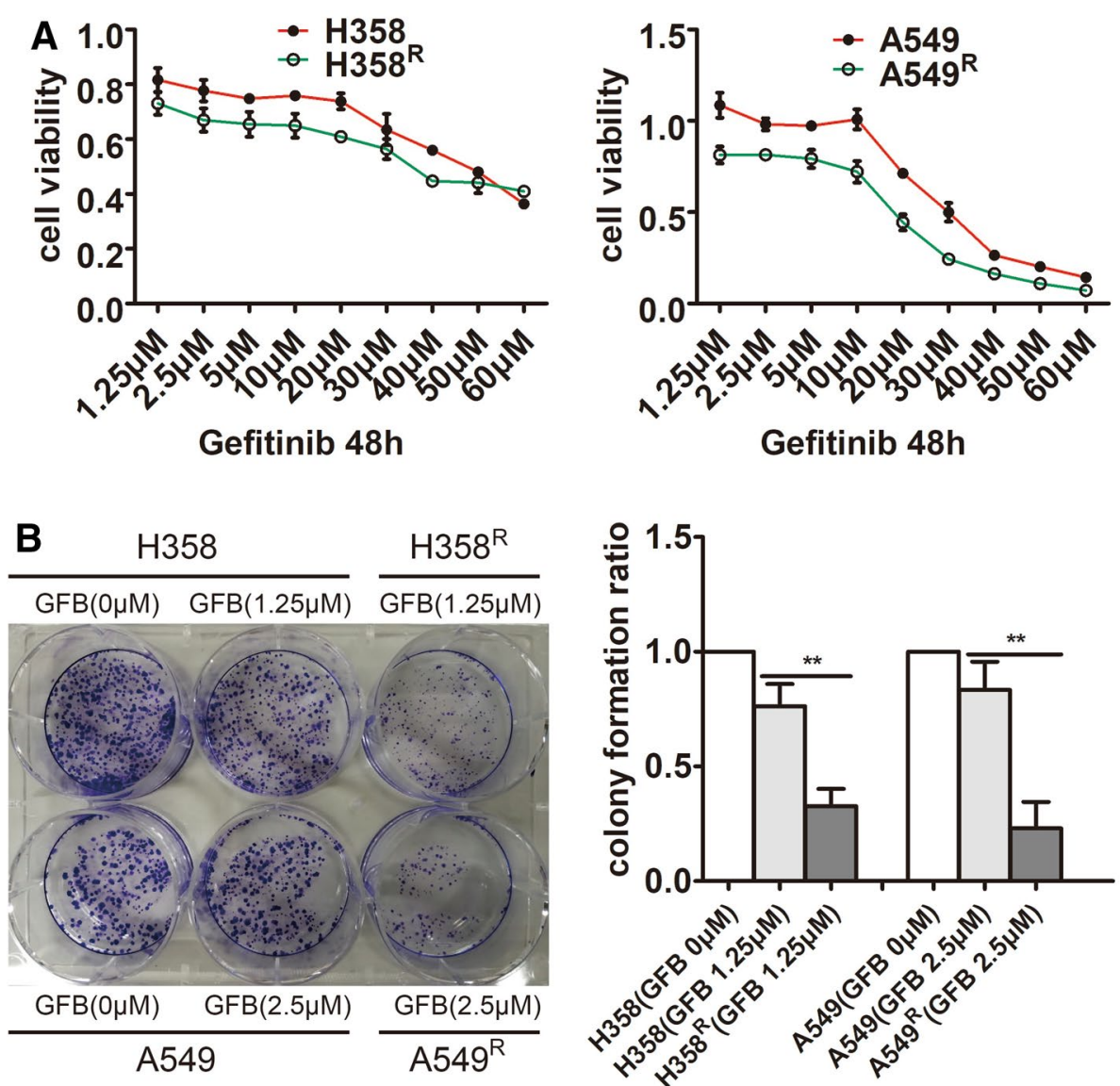

\section{Gefitinib combined with cisplatin significantly inhibits proliferation of $H 358^{R}$ and $A 549^{R}$ cells}

After determining the concentration of gefitinib, we observed the effect of gefitinib combined with cisplatin on the proliferation and viability of $\mathrm{H} 358^{\mathrm{R}}$ and $\mathrm{A} 549^{\mathrm{R}}$ cells. We treated $\mathrm{H} 358^{\mathrm{R}} / \mathrm{A} 549^{\mathrm{R}}$ cells and their parental cells with the $\mathrm{IC}_{50}$ to cisplatin $48 \mathrm{~h}$ of the parental cell lines, respectively. MTT assay showed the cell growth inhibition ratio of cisplatin on $\mathrm{H} 358^{\mathrm{R}} / \mathrm{A} 549^{\mathrm{R}}$ cells was significantly lower than that of their parental cells. However, after combining with gefitinib, the inhibition ratio was significantly improved (Fig. 5a). In addition, clone formation experiments showed that gefitinib combined with cisplatin can effectively inhibit the proliferation of $\mathrm{H} 358^{\mathrm{R}} / \mathrm{A} 549^{\mathrm{R}}$ cells (Fig. $5 \mathrm{~b}$ ). And the above experiments showed that compared with the parental cell lines, the sensitivity of cisplatin on $H 358^{R} / A 549^{R}$ cells has been largely restored when the two drugs were in combination.

S6K and eIF4EBP1 are the most important molecules downstream of EGFR/AKT/ERK that directly regulate protein synthesis and promote cell proliferation (JhanwarUniyal et al. 2017). We tested the phosphorylation levels of these molecules in $\mathrm{H} 358^{\mathrm{R}} / \mathrm{A} 549^{\mathrm{R}}$ cells after gefitinib combined with cisplatin treatment. The results showed that the combination of two drugs can significantly reduce phosphorylation level of S6K and eIF4EBP1 (Fig. 5c), which explains the anti-proliferative effect of the combination of gefitinib and cisplatin.

\section{Gefitinib combined with cisplatin promotes $S$ arrest in $\mathrm{H} 358^{\mathrm{R}}$ and $\mathrm{A} 549^{\mathrm{R}}$ cells}

To investigate whether gefitinib combined with cisplatininduced inhibition of cell proliferation was associated with 


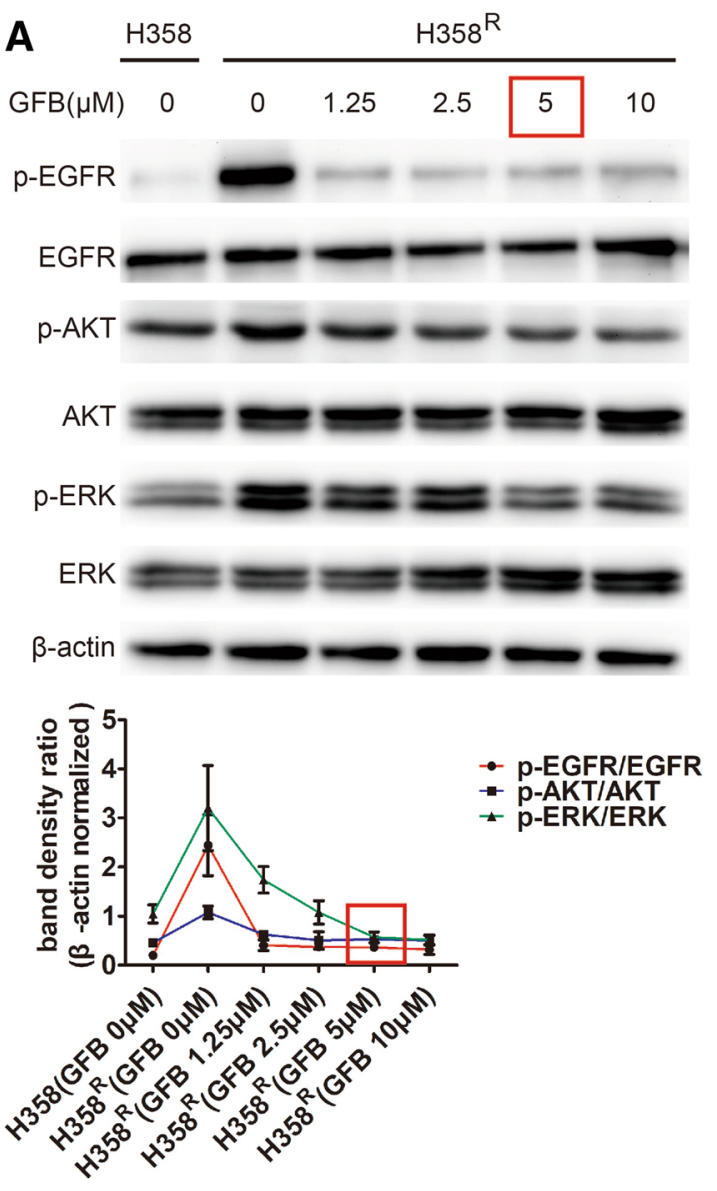

Fig. 4 Gefitinib (GFB) inhibited EGFR/AKT/ERK phosphorylation in $\mathrm{H} 358^{\mathrm{R}}$ and $\mathrm{A} 549^{\mathrm{R}}$ cells. a Detected EGFR/AKT/ERK phosphorylation levels after $48 \mathrm{~h}$ of gefitinib (GFB) at different intervention concentrations by western blot. The minimum concentration of gefitinib

cell-cycle dysregulation, we analyzed the effect of gefitinib on cell-cycle progression in cisplatin-treated $\mathrm{H} 358^{\mathrm{R}} / \mathrm{A} 549^{\mathrm{R}}$ cells based on DNA content by propidium iodide staining of flow cytometry analysis. With $\mathrm{H} 358^{\mathrm{R}}$ cells treated with cisplatin and gefitinib individually, there was an increase in the percentage of cells in the S and G0/G1 phase compared with the percentage in controls, respectively. With combined cispaltin and gefitinib treatment, the percentages of $\mathrm{H} 358^{\mathrm{R}}$ cells in the $\mathrm{S}$ phase were further improved, compared with the values of their monotherapy group (Fig. 6a). The percentage of $A 549^{R}$ cells in the G2/M and G0/G1 phase was increased after cisplatin and gefitinib treatment and similar results were obtained when gefitinib combined with cispaltin

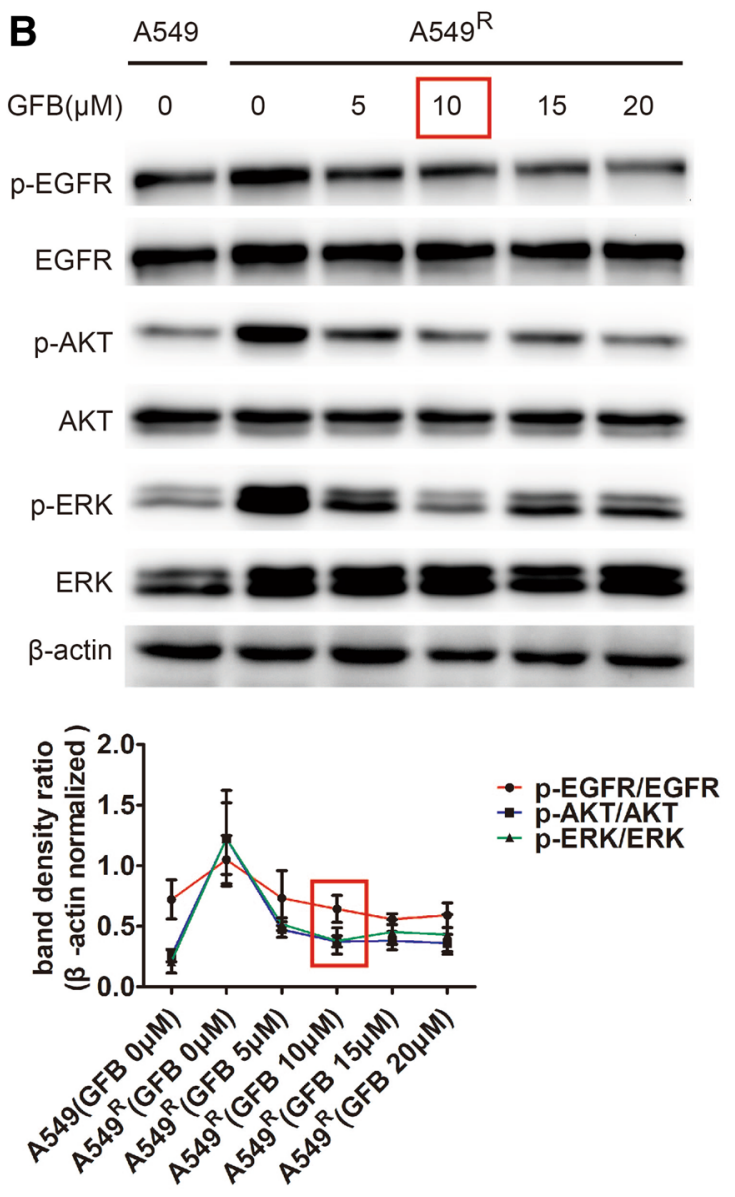

(GFB) inhibiting p-EGFR, p-AKT, p-ERK in $\mathrm{H} 358^{\mathrm{R}}$ is $5 \mu \mathrm{M}$. b Similarly, $10 \mu \mathrm{M}$ gefitinib (GFB) could simultaneously inhibit p-EGFR, p-AKT, p-ERK in A549 ${ }^{\mathrm{R}}$ cells

was used simultaneously (Fig. 6b). Collectively, these results suggest gefitinib combined with cisplatin promotes $\mathrm{S}$ arrest and blocks cell-cycle progression in $\mathrm{H} 358^{\mathrm{R}}$ and $\mathrm{A} 549^{\mathrm{R}}$ cells.

The proteins cyclin A and CDK2 govern S-to-G2/M phase progression, and down-regulation of them leads to S phase arrest (Oakes et al. 2014). Thus, we examined the expression of endogenous cyclin $\mathrm{A}, \mathrm{CDK} 2$. As indicated in Fig. 6c, cyclin A and CDK2 values were further reduced in the $\mathrm{H} 358^{\mathrm{R}} / \mathrm{A} 549^{\mathrm{R}}$ cell lines when treated with cisplatin plus gefitinib. These data indicate that cisplatin and gefitinib in combination enhanced cells arrest at $\mathrm{S}$ phase mainly through the down-regulation of the key $\mathrm{S}$ phase regulatory proteins cyclin A and CDK2. 
A
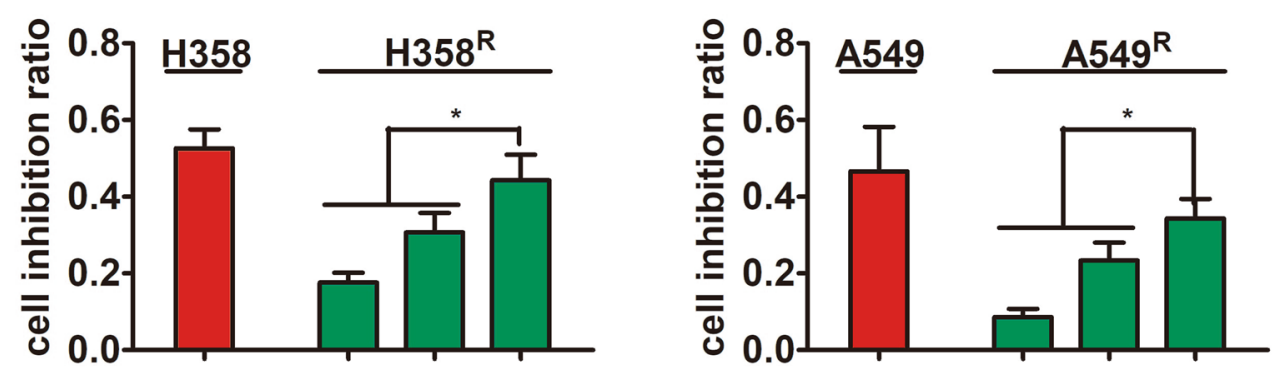

B
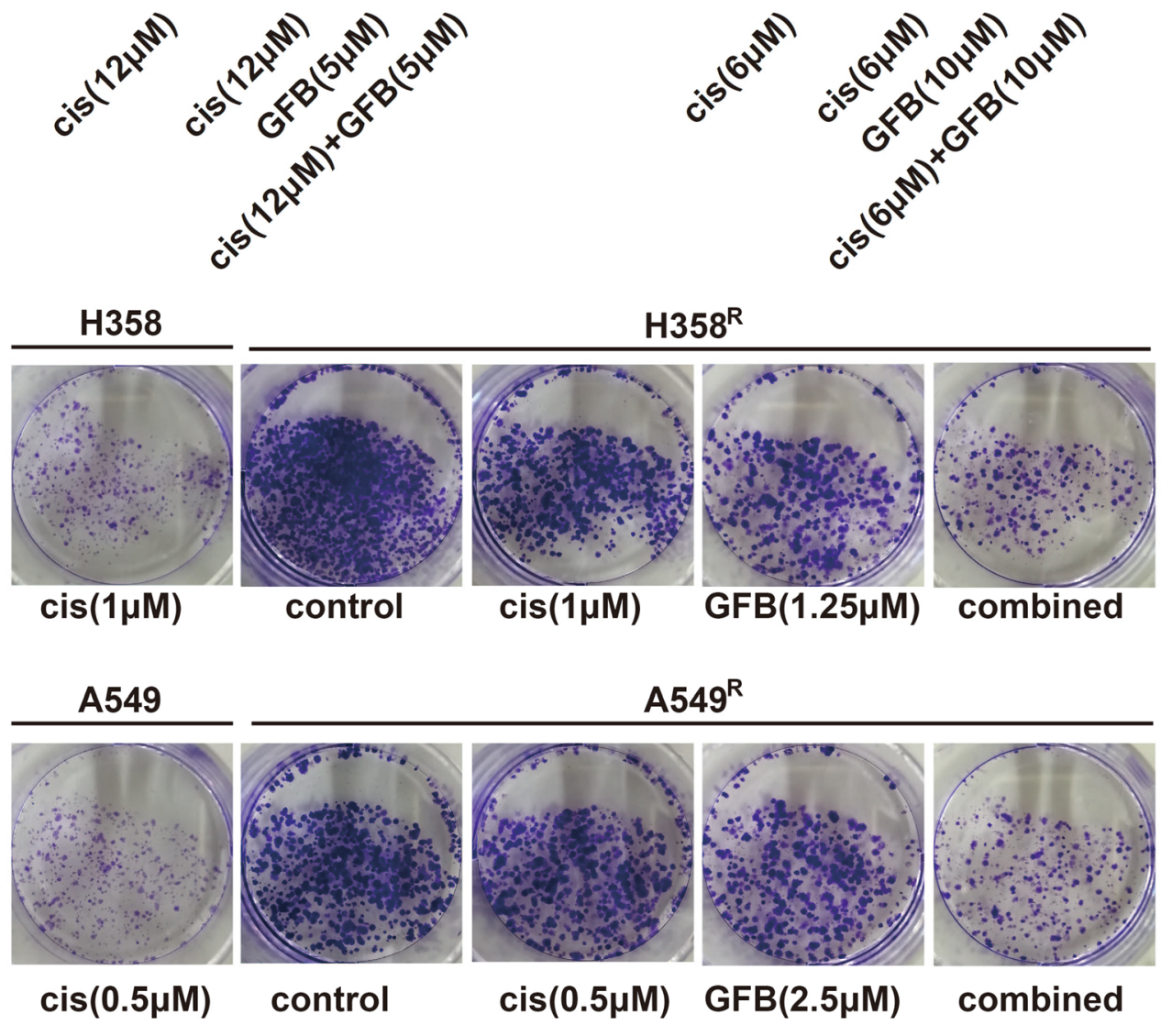

A549 ${ }^{R}$

C
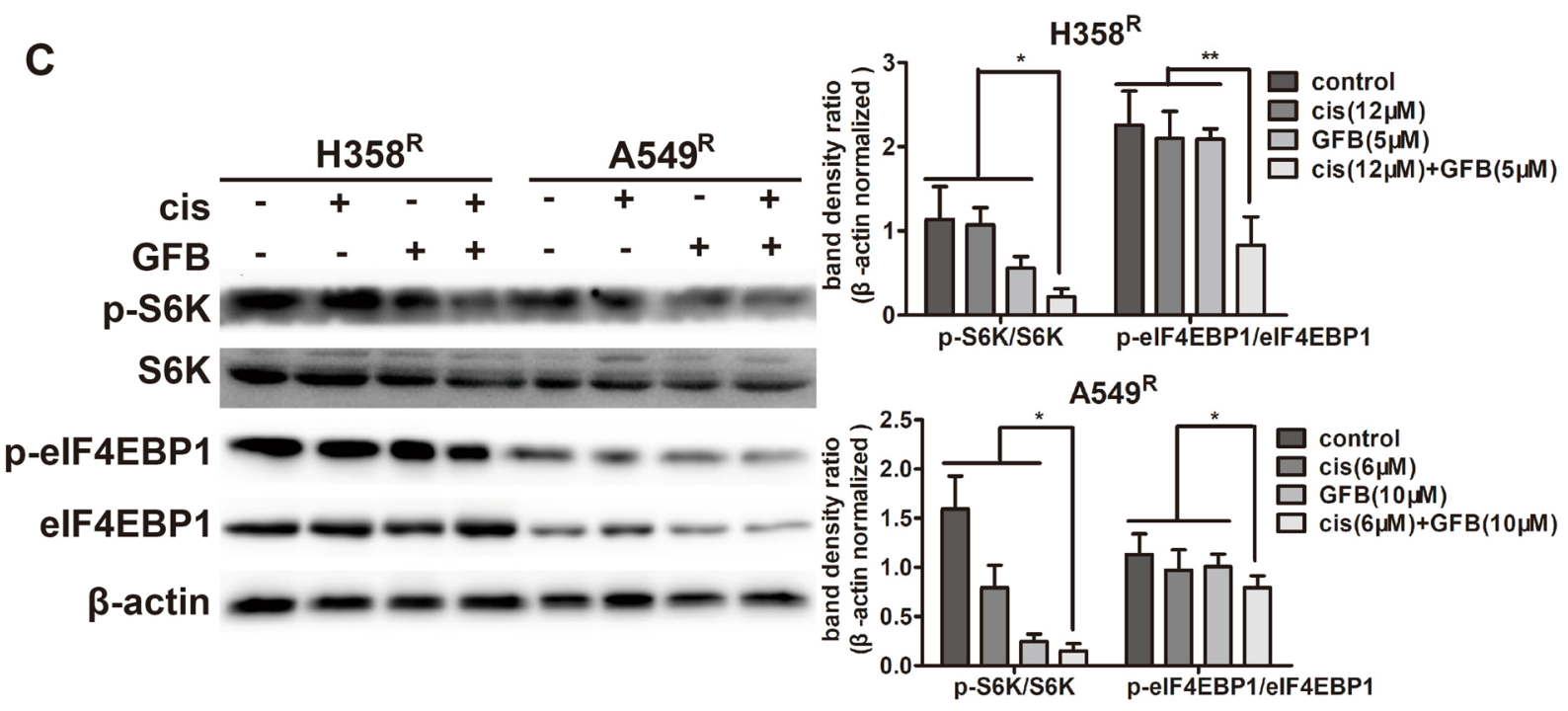
4Fig. 5 Gefitinib (GFB) combined with cisplatin (cis) significantly inhibits proliferation of $\mathrm{H} 358^{\mathrm{R}}$ and $\mathrm{A} 549^{\mathrm{R}}$ cells. a Inhibition ratio of cells incubated with cisplatin (cis), gefitinib (GFB), or a combination of two drugs for $48 \mathrm{~h}$, was measured with MTT assay. b Proliferation inhibition of cells incubated with cisplatin (cis), gefitinib (GFB), or a combination of two drugs for $24 \mathrm{~h}$, was measured with clone formation assay. $\mathbf{c}$ Expression of related proliferation regulation protein in $\mathrm{H} 358^{\mathrm{R}}$ and $\mathrm{A} 549^{\mathrm{R}}$ cells incubated with cisplatin (cis), gefitinib (GFB), or a combination of two drugs for $48 \mathrm{~h}$, was detected by western blot $(* P<0.05, * * P<0.01)$

\section{Gefitinib combined with cisplatin enhances the mitochondrial apoptosis in $\mathrm{H}_{358^{\mathrm{R}}}$ and $\mathrm{A549}{ }^{\mathrm{R}}$ cells}

To evaluate the apoptotic effect of gefitinib combined with cisplatin in $\mathrm{H} 358^{\mathrm{R}}$ and $\mathrm{A} 549^{\mathrm{R}}$ cells, Annexin V-FITC/PI staining, cell mitochondrial membrane potential measurement (JC-1), and western blot were performed. As shown in Fig. 7a, flow cytometry analysis of AnnexinV-FITC/PI staining displayed that gefitinib combined with cisplatin had a significantly higher apoptosis ratio than cisplatin alone in $\mathrm{H} 358^{\mathrm{R}} / \mathrm{A} 549^{\mathrm{R}}$ cells. In Fig. $7 \mathrm{~b}, \mathrm{JC}-1$ staining showed the green fluorescence intensity of $\mathrm{H} 358^{\mathrm{R}} / \mathrm{A} 549^{\mathrm{R}}$ cells treated with cisplatin monotherapy increased only slightly. However, when combining with gefitinib, the green fluorescence intensity was significantly enhanced. And the green fluorescence intensity of the combined group was very close to that of the parent cell lines treated with cisplatin. Gefitinib combined with cisplatin reduced mitochondrial membrane potential also indicates the effect of enhanced mitochondrial apoptosis in $\mathrm{H} 358^{\mathrm{R}} / \mathrm{A} 549^{\mathrm{R}}$ cells.

Correspondingly, western blot experiments (Fig. 7c) showed that after gefitinib combined with cisplatin treatment, cleaved caspase- 9 , cleaved caspase- 3 , cleaved caspase-7 levels detected in $\mathrm{H} 358^{\mathrm{R}} / \mathrm{A} 549^{\mathrm{R}}$ cells were more higher than that in cisplatin treatment group. These results prove that gefitinib/cisplatin combined can promote the apoptosis of cisplatin-resistant $\mathrm{H} 358^{\mathrm{R}} / \mathrm{A} 549^{\mathrm{R}}$ cells and restore most of the sensitivity of these cells to cisplatin.

\section{Gefitinib enhances the anti-tumor effect of cisplatin in $\mathrm{H}_{358^{\mathrm{R}}}$ xenograft in vivo}

The anti-tumor effect of gefitinib combined with cisplatin was evaluated in the $\mathrm{H} 358^{\mathrm{R}}$ tumor-bearing nude mouse model. Tumor growth was measured twice a week and represented on the graph in Fig. 8a, b. As expected, cisplatin had moderate anti-tumor activity at a dose of $2 \mathrm{mg} / \mathrm{kg}$ because of its resistance. However, when combined with gefitinib, the tumor growth was significantly suppressed, and there was a steady trend of reduced tumor volume. The weight of the tumor-bearing mice had a stable trend, and

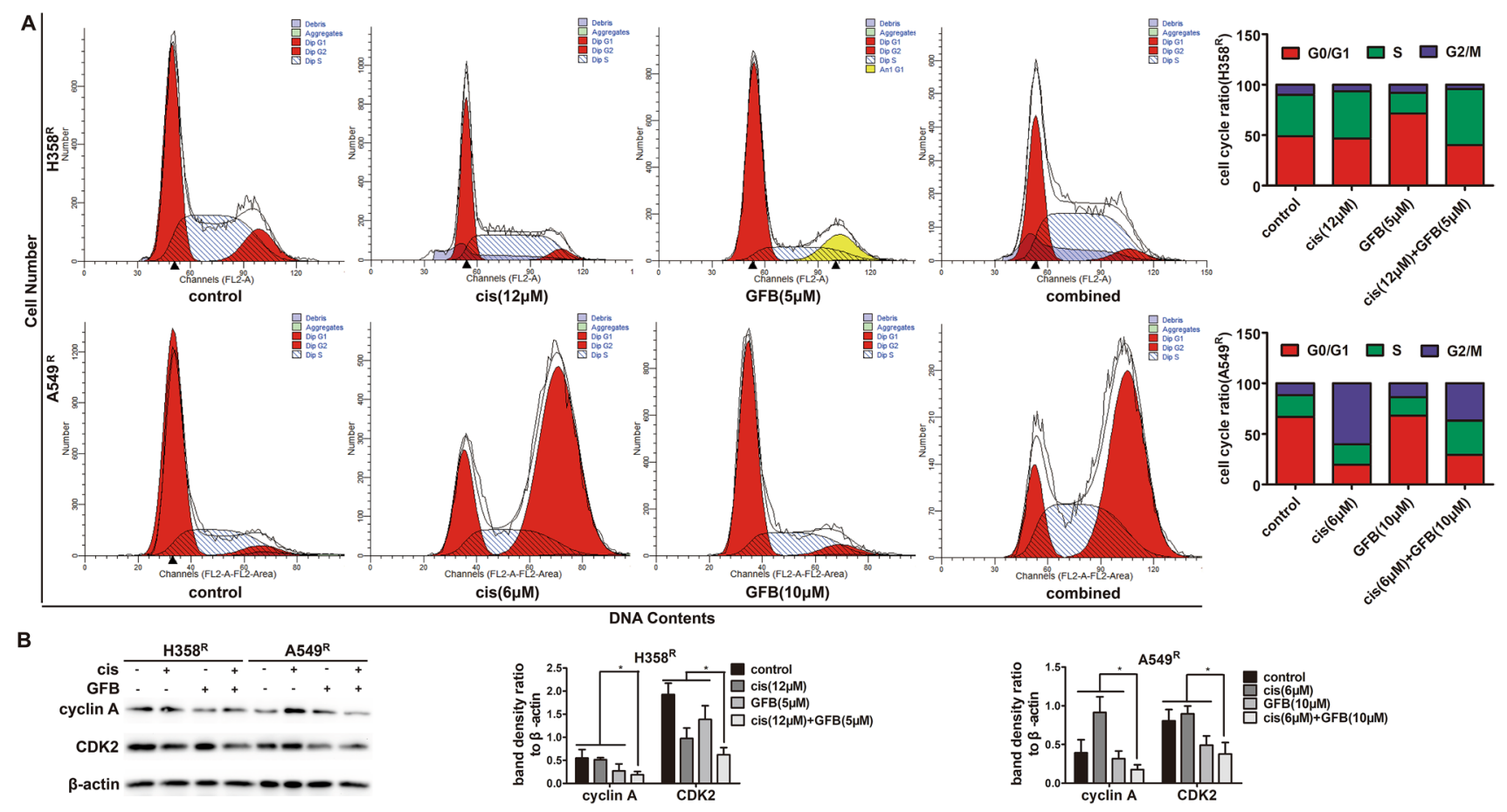

Fig. 6 Gefitinib (GFB) combined with cisplatin (cis) promotes $\mathrm{S}$ arrest in $\mathrm{H} 358^{\mathrm{R}}$ and $\mathrm{A} 549^{\mathrm{R}}$ cells. a The percentages of $\mathrm{H} 358^{\mathrm{R}}$ and $\mathrm{A} 549^{\mathrm{R}}$ cells in the $\mathrm{S}$ phase were improved when incubated with a combination of cisplatin (cis) and gefitinib (GFB) for $48 \mathrm{~h}$, was analyzed by flow cytometry. b Cyclin A and CDK2 expression of S phase regulatory proteins in $\mathrm{H} 358^{\mathrm{R}}$ and $\mathrm{A} 549^{\mathrm{R}}$ cells incubated with drugs for $48 \mathrm{~h}$, was detected by western blot $\left({ }^{*} P<0.05\right)$ 
A

H358

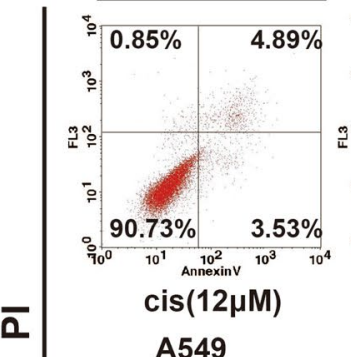

$\bar{\alpha}$

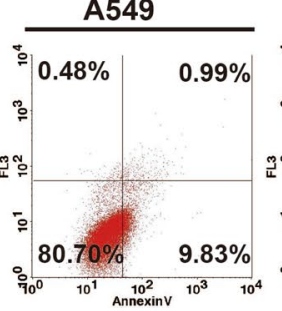

$\operatorname{cis}(6 \mu \mathrm{M})$

B

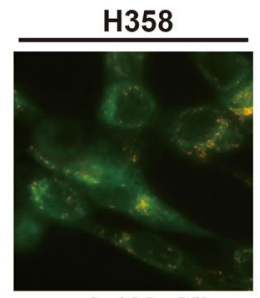

$\operatorname{cis}(12 \mu \mathrm{M})$

A549

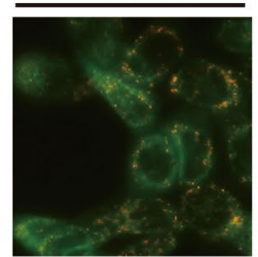

$\operatorname{cis}(6 \mu \mathrm{M})$

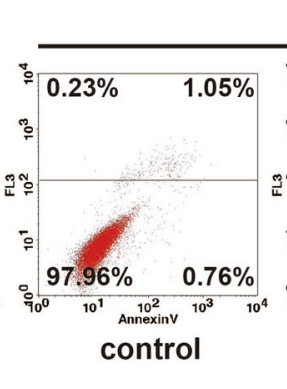

$\mathrm{H} 358^{\mathrm{R}}$

\begin{tabular}{|l|l|l|l|}
\hline & & \\
\hline
\end{tabular}
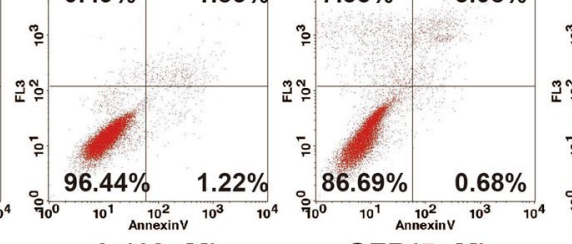

:-

-

\begin{tabular}{l|l}
$91.96 \%$ & $3.59 \%$ \\
\hline
\end{tabular}

$$
\text { cis }(12 \mu \mathrm{M})
$$

Annexinv
GFB $(5 \mu M)$

combined $A 549^{R}$

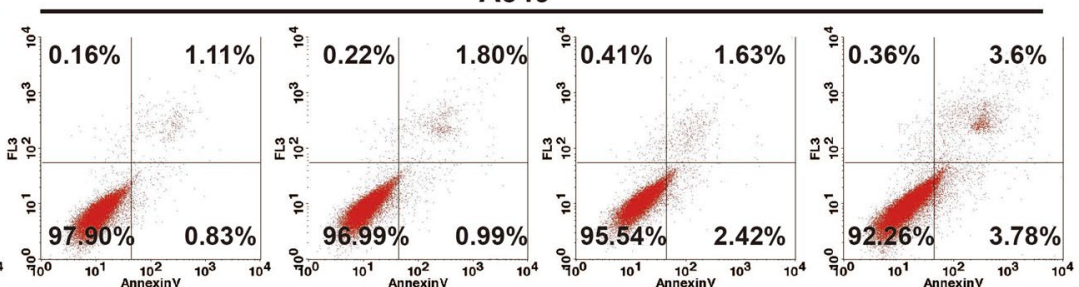

$\operatorname{cis}(6 \mu M)$

GFB $(10 \mu M)$ combined

\section{Annexin V-FITC}

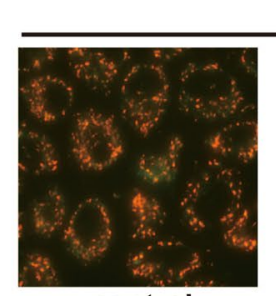

control

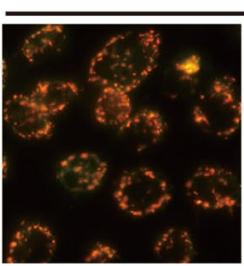

control
$H 358^{R}$

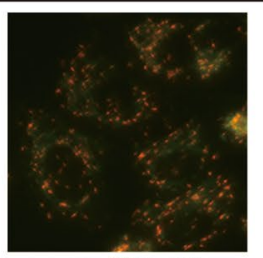

$\operatorname{cis}(12 \mu \mathrm{M})$

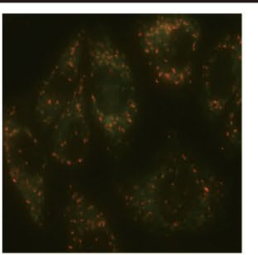

GFB $(5 \mu M)$

A549R

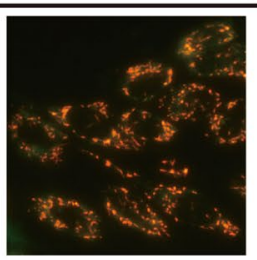

$\operatorname{cis}(6 \mu \mathrm{M})$

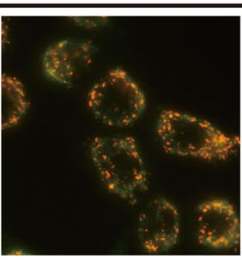

GFB(10 $\mu M)$

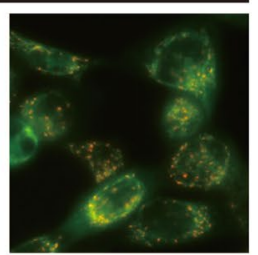

combined

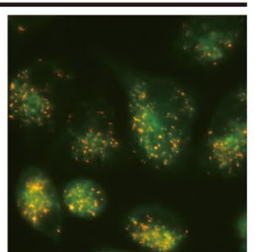

combined

C
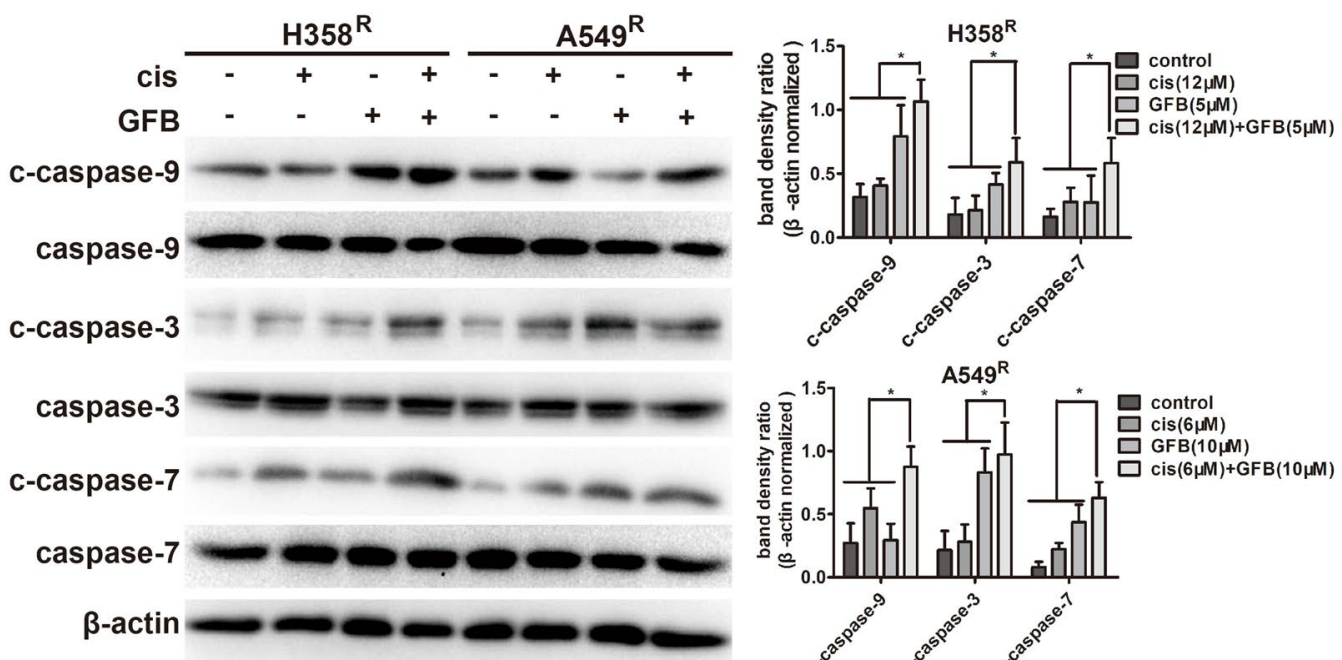
4Fig.7 Gefitinib (GFB) combined with cisplatin (cis) enhances the mitochondrial apoptosis in $\mathrm{H} 358^{\mathrm{R}}$ and $\mathrm{A} 549^{\mathrm{R}}$ cells. a Apoptosis ratio of cells incubated with cisplatin (cis), gefitinib (GFB), or a combination of two drugs for $48 \mathrm{~h}$, was analyzed by flow cytometry. b Fluorescence microscope viewed mitochondrial membrane potential of cells after drugs treatment $48 \mathrm{~h}$ by JC- 1 staining. $\mathbf{c}$ Expression of mitochondrial apoptosis-related protein in $\mathrm{H} 358^{\mathrm{R}}$ and $\mathrm{A} 549^{\mathrm{R}}$ cells when cisplatin (cis), gefitinib (GFB), or a combination of two drugs treatment $48 \mathrm{~h}$, was examined by western blot $\left(* P<0.05,{ }^{*} * P<0.01\right)$

weights of the treated mice were slightly lower than those of the tumor-bearing control mice (Fig. 8c). Thus, these in vivo findings are evidence of the anti-tumor effect of cisplatin enhanced by gefitinib in cisplatin-resistant $\mathrm{H} 358^{\mathrm{R}}$ xenograft.

\section{Discussion}

wtEGFR NSCLC is the major histological form of epithelial lung cancer, and it remains the principle cause of cancerrelated death. Although advances in molecular diagnosis and targeted therapies have been providing personalized therapies that translate into clinically meaningful benefits, for patients with advanced wtEGFR NSCLC, cisplatinbased chemotherapy is still the first-line treatment option (Griesinger et al. 2019). However, drug resistances are often inevitable accompanied by the long-term use of cisplatin, significantly hampering its therapeutic efficacy and clinical outcomes (Lin et al. 2019). The purpose of our research is to explore the mechanism of cisplatin resistance and clinical strategies to release or reduce the resistance.
In the study, we developed two cisplatin-resistant wtEGFR NSCLC cell lines $\mathrm{H} 358^{\mathrm{R}} / \mathrm{A} 549^{\mathrm{R}}$ and found that EGFR was significantly activated in these cells. Moreover, they were more sensitive to EGFR inhibitor gefitinib than their parental cells, suggesting that cisplatin resistance is associated with abnormal activation of EGFR. EGFR is a transmembrane receptor protein and the complex cross-talk with several membrane receptors, including the other members of the erbB/HER-family (Roskoski 2014) involved in the fine regulation of epithelial cell proliferation, anti-apoptosis, angiogenesis and drug resistance (Leon et al. 2016). Its complicated downstream signaling pathways, especially PI3K/ AKT/mTOR and Ras/Raf/MAPK, achieve the multiplicity of biological effects induced by EGFR activation (Cao et al. 2019). In this work, we found that the EGFR and downstream node molecules AKT/ERK in PI3K/AKT/mTOR and Ras/ Raf/MAPK pathways were indeed abnormally activated, and their activities were significantly reduced when application of gefitinib in $\mathrm{H} 358^{\mathrm{R}} / \mathrm{A} 549^{\mathrm{R}}$ cell lines.

It is noteworthy that these two cell lines sensitized to gefitinib by cisplatin induced express mutated KRAS. The KRAS mutation has been used as a predictive marker of low sensitivity to EGFR-TKI in lung cancer cells harboring EGFR activating mutations (Timar 2014). However, whether the KRAS mutation affects the response of wtEGFR NSCLC to EGFR-TKI is still controversial (Ulivi et al. 2014). It has shown KRAS status does not affect the cell survival/growth and phosphorylation of AKT/ERK kinases in wtEGFR NSCLC (Ihle et al. 2012), the EGFR, AKT and ERK phosphorylation induced by cisplatin in our KRAS-mutated cell lines would thus not involve KRAS. And KRAS does not
Fig. 8 Gefitinib enhances the anti-tumor effect of cisplatin in $\mathrm{H} 358^{\mathrm{R}}$ xenograft in vivo. a Tumor volume of xenograft tumors $\left(\mathrm{H} 358^{\mathrm{R}}\right)$ treated with cisplatin, gefitinib, and cisplatin + gefitinib, respectively. b Growth curves of xenograft tumors $\left(\mathrm{H} 358^{\mathrm{R}}\right)$ in each treatment group. c Body weight changes of model mouses in each treatment group during the treatment period
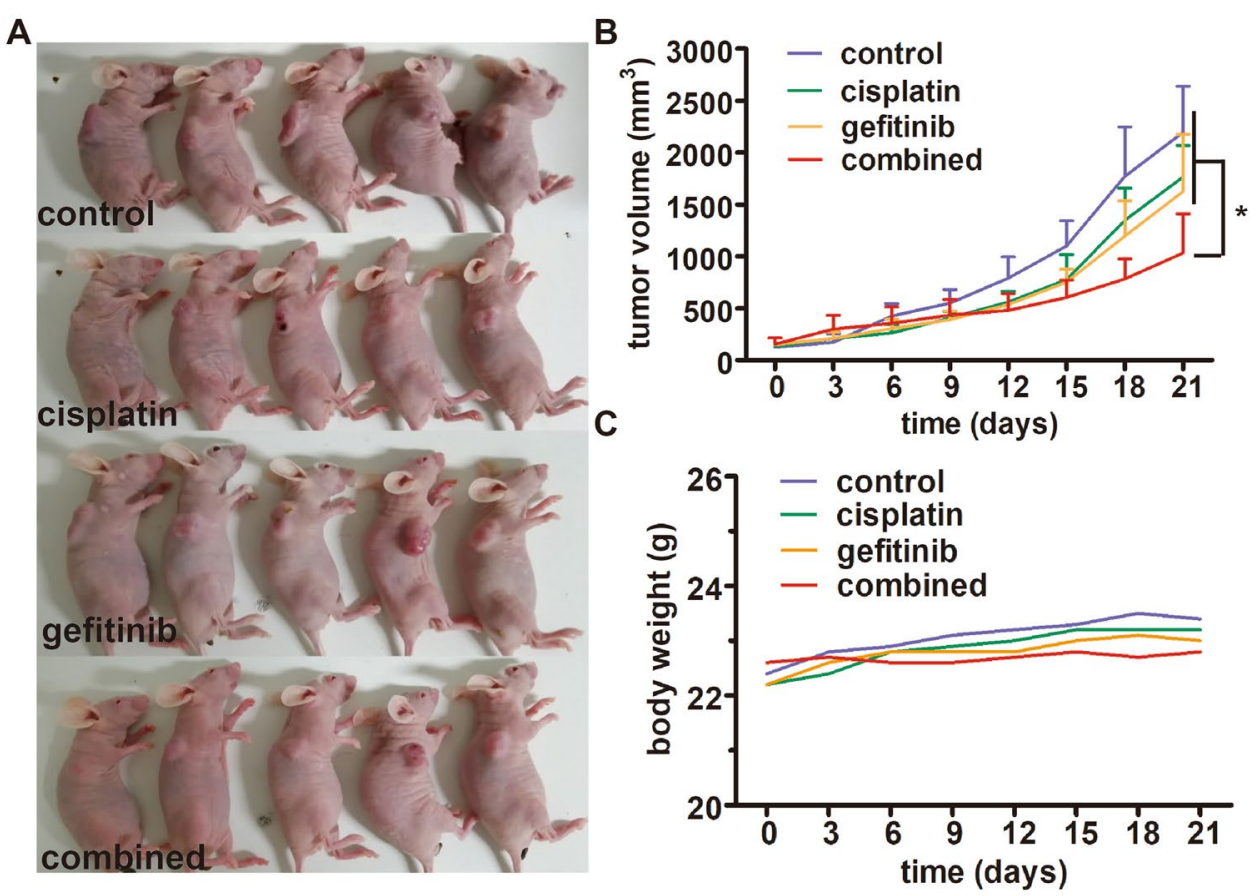
appear as a major determinant for the mechanism of gefitinib sensitization described in our study.

Gefitinib is an aniline quinazoline derivative. It blocks tumor growth, metastasis, angiogenesis, and promotes tumor cell apoptosis by inhibiting EGFR-tyrosine kinase and blocking the EGFR signaling pathway (Zhang et al. 2017; Wang et al. 2019). The benefit of gefitinib has been demonstrated in mutant EGFR NSCLC as first-line treatment, but in wtEGFR NSCLC, gefitinib is restricted to maintenance therapy in pretreated patients (Choi et al. 2015; Landi and Cappuzzo 2015). From the analysis of our research results, sensitized gefitinib can not only be used as maintenance treatment for cisplatin-resistant patients, but also be used in combination with cisplatin to improve drug sensitivity, enhancing anti-tumor efficacy in patients with cisplatin-resistant wtEGFR NSCLC.

At the cytological level, we described the effect of gefitinib in combination with cisplatin in $\mathrm{H} 358^{\mathrm{R}} / \mathrm{A} 549^{\mathrm{R}}$ cell lines. The anti-proliferative and pro-apoptotic activities of gefitinib and cisplatin in combination were increased compared with that of them monotherapy. In particular, the combined effect of the two drugs was close to that of cisplatin on parental cells. Similarly, in vivo, geifitinib and cisplatin combined treatment had a greater inhibitory effect on $\mathrm{H} 358^{\mathrm{R}}$ xenograft growth than did either drug alone. The fact of anti-tumor effect significantly enhanced when gefitinib and cisplatin combined administration suggests a novel combination treatment strategy for cisplatinresistant wtEGFR NSCLC that deserves clinical study.

By detecting EGFR/AKT/ERK downstream molecules, gefitinib combined with cisplatin significantly inhibited regulatory proteins associated with cell proliferation, cell cycle and mitochondrial apoptosis, which was consistent with anti-proliferative and pro-apoptotic effects. Considering the intricate signal networks and the frequent crosstalk between the pathways in the cell, we have not studied the upstream regulatory mechanism of these molecules. The combined dose of cisplatin also needs to be further explored to achieve the optimal ratio with gefitinib and exert the greatest anti-tumor effect, even if $\mathrm{IC}_{50}$ to cisplatin of sensitive cell lines was used in our experiment. In addition, whether this combination therapy strategy is suitable for other types of cisplatin-resistant wtEGFR NSCLC cells also requires further research, as we have only tested this two cell lines H358 and A549. These questions and the molecular mechanism of cisplatin to regulate EGFR activation will be the content of our subsequent research.

\section{Conclusion}

EGFR is abnormally activated in our induced cisplatinresistant cell lines, and these cells have increased sensitivity to gefitinib. Gefitinib combined with cisplatin significantly enhances anti-tumor effects in vitro and in vivo. These results suggest that gefitinib and cisplatin in combination is a promising strategy for treating cisplatinresistant wtEGFR NSCLC.

Acknowledgements We thank Professor Emeritus, William R. Brown, M.D. (University of Colorado School of Medicine Denver CO USA) for revising the manuscript, and we would also like to acknowledge our families for their support and understanding, even during the outbreak of a new coronavirus in China. In addition, we very thank the experimental mice for their dedication to our research.

Author contributions XT and AL conceived and designed the study. WC, XL and YZ performed the biological methodology. YM and RX performed molecular analysis and acquisition of data: RZ, XL and SZ were the data manager for the study. AL drafted the manuscript; RW and JL carried out a critical revision of the manuscript for important intellectual content. All authors read and approved the final version of the manuscript.

Funding None.

Data availability Yes.

\section{Compliance with ethical standards}

\section{Conflict of interest None.}

Ethical approval All animal experiments were carried out in accordance with the principles and procedures approved by the Committee on the Ethics of Animal Experiments of Anhui University of Science and Technology.

Consent to participate Yes.

Consent for publication Yes.

Availability of data and material Yes.

Code availability Yes.

\section{References}

Cao Q, You X, Xu L, Wang L, Chen Y (2019) PAQR3 suppresses the growth of non-small cell lung cancer cells via modulation of EGFR-mediated autophagy. Autophagy 30:1-12

Chen HH, Yan JJ, Chen WC, Kuo MT, Lai YH, Lai WW, Liu HS, Su WC (2012) Predictive and prognostic value of human copper transporter 1 (hCtr1) in patients with stage III non-small-cell lung cancer receiving first-line platinum-based doublet chemotherapy. Lung Cancer 75:228-234

Choi MK, Hong JY, Chang WJ, Kim MJ, Kim SM, Jung HA, Do IG, Choi YL, Sun JM, Ahn JS, Park K, Ahn MJ (2015) A phase II trial of gefitinib monotherapy in pretreated patients with advanced nonsmall cell lungcancer not harboring activating EGFR mutations: implications of sensitive EGFR mutation test. Cancer Chemother Pharmacol 75:1229-1236

Chou TC (2006) Theoretical basis, experimental design, and computerized simulation of synergism and antagonism in drug combination studies. Pharmacol Rev 58:621-681 
de La Motte RT, Galluzzi L, Olaussen KA, Zermati Y, Tasdemir E, Robert T, Ripoche H, Lazar V, Dessen P, Harper F, Pierron G, Pinna G, Araujo N, Harel-Belan A, Armand JP, Wong TW, Soria JC, Kroemer G (2007) A novel epidermal growth factor receptor inhibitor promotes apoptosis in non-small cell lung cancer cells resistant to erlotinib. Cancer Res 67:6253-6262

Friboulet L, Olaussen KA, Pignon JP, Shepherd FA, Tsao MS, Graziano S, Kratzke R, Douillard JY, Seymour L, Pirker R, Filipits M, André F, Solary E, Ponsonnailles F, Robin A, Stoclin A, Dorvault N, Commo F, Adam J, Vanhecke E, Saulnier P, Thomale J, Le Chevalier T, Dunant A, Rousseau V, Le Teuff G, Brambilla E, Soria JC (2013) ERCC1 isoform expression and DNA repair in non-small-cell lung cancer. N Engl J Med 368:1101-1110

Galluzzi L, Senovilla L, Vitale I, Michels J, Martins I, Kepp O, Castedo M, Kroemer G (2012) Molecular mechanisms of cisplatin resistance. Oncogene 31:1869-1883

Goloudina AR, Tanoue K, Hammann A, Fourmaux E, Le Guezennec X, Bulavin DV, Mazur SJ, Appella E, Garrido C, Demidov ON (2012) Wip1 promotes RUNX2-dependent apoptosis in p53-negative tumors and protects normal tissues during treatment with anticancer agents. Proc Natl Acad Sci USA 109:E68-E75

Griesinger F, Korol EE, Kayaniyil S, Varol N, Ebner T, Goring SM (2019) Efficacy and safety of first-line carboplatin-versus cisplatin-based chemotherapy for non-small cell lung cancer: a metaanalysis. Lung Cancer 135:196-204

Guo G, Gong K, Wohlfeld B, Hatanpaa KJ, Zhao D, Habib AA (2015) Ligand-independent EGFR signaling. Cancer Res 75:3436-3441

Hardbower DM, Singh K, Asim M, Verriere TG, Olivares-Villagómez D, Barry DP, Allaman MM, Washington MK, Peek RM Jr, Piazuelo MB, Wilson KT (2016) EGFR regulates macrophage activation and function in bacterial infection. J Clin Investig 126:3296-3312

Ihle NT, Byers LA, Kim ES, Saintigny P, Lee JJ, Blumenschein GR, Tsao A, Liu S, Larsen JE, Wang J, Diao L, Coombes KR, Chen L, Zhang S, Abdelmelek MF, Tang X, Papadimitrakopoulou V, Minna JD, Lippman SM, Hong WK, Herbst RS, Wistuba II, Heymach JV, Powis G (2012) Effect of KRAS oncogene substitutions on protein behavior: implications for signaling and clinical outcome. J Nat Cancer Inst 104:228-239

Ishida S, McCormick F, Smith-McCune K, Hanahan D (2010) Enhancing tumor-specific uptake of the anticancer drug cisplatin with a copper chelator. Cancer Cell 17:574-583

Jhanwar-Uniyal M, Amin AG, Cooper JB, Das K, Schmidt MH, Murali R (2017) Discrete signaling mechanisms of mTORC1 and mTORC2: connected yet apart in cellular and molecular aspects. Adv Biol Regul 64:39-48

Kamal NS, Soria JC, Mendiboure J, Planchard D, Olaussen KA, Rousseau V, Popper H, Pirker R, Bertrand P, Dunant A, Le Chevalier T, Filipits M, Fouret $P$ (2010) International adjuvant lung trialbio investigators. MutS homologue 2 and the long-term benefit of adjuvant chemotherapy in lung cancer. Clin Cancer Res 16:1206-1215

Kuo MT, Fu S, Savaraj N, Chen HH (2012) Role of the human highaffinity copper transporter in copper homeostasis regulation and cisplatin sensitivity in cancer chemotherapy. Cancer Res 72:4616-4621

Landi L, Cappuzzo F (2015) Experience with erlotinib in the treatment of non-small cell lung cancer. Ther Adv Respir Dis 9:146-163

Leon G, MacDonagh L, Finn SP, Cuffe S, Barr MP (2016) Cancer stem cells in drug resistant lung cancer: targeting cell surface markers and signaling pathways. Pharmacol Ther 158:71-90

Lin YX, Wang Y, An HW, Qi B, Wang J, Wang L, Shi J, Mei L, Wang H (2019) Peptide-based autophagic gene and cisplatin co-delivery systems enable improved chemotherapy resistance. Nano Lett 19:2968-2978
Lu N, Wang L, Cao H, Liu L, Van Kaer L, Washington MK, Rosen MJ, Dubé PE, Wilson KT, Ren X, Hao X, Polk DB, Yan F (2014) Activation of the epidermal growth factor receptor in macrophages regulates cytokine production and experimental colitis. J Immunol 192:1013-1023

Michaud WA, Nichols AC, Mroz EA, Faquin WC, Clark JR, Begum S, Westra WH, Wada H, Busse PM, Ellisen LW, Rocco JW (2009) Bcl-2 blocks cisplatin-induced apoptosis and predicts poor outcome following chemoradiation treatment in advanced oropharyngeal squamous cell carcinoma. Clin Cancer Res 15:1645-1654

Oakes V, Wang W, Harrington B, Lee WJ, Beamish H, Chia KM, Pinder A, Goto H, Inagaki M, Pavey S, Gabrielli B (2014) Cyclin $\mathrm{A} / \mathrm{Cdk} 2$ regulates $\mathrm{Cdh} 1$ and claspin during late $\mathrm{S} / \mathrm{G} 2$ phase of the cell cycle. Cell Cycle 13:3302-3311

Olaussen KA, Dunant A, Fouret P, Brambilla E, André F, Haddad V, Taranchon E, Filipits M, Pirker R, Popper HH, Stahel R, Sabatier L, Pignon JP, Tursz T, Le Chevalier T, Soria JC (2006) IALT bio investigators. DNA repair by ERCC1 in non-small-cell lung cancer and cisplatin-based adjuvant chemotherapy. N Engl J Med 355:983-991

Reck M, Heigener DF, Mok T, Soria JC, Rabe KF (2013) Management of non-small-cell lung cancer: recent developments. Lancet 382:709-719

Ren JH, He WS, Nong L, Zhu QY, Hu K, Zhang RG, Huang LL, Zhu F, Wu G (2010) Acquired cisplatin resistance in human lung adenocarcinoma cells is associated with enhanced autophagy. Cancer Biother Radiopharm 25:75-80

Roskoski R Jr (2014) The ErbB/HER family of protein-tyrosine kinases and cancer. Pharmacol Res 79:34-74

Shen DW, Ma J, Okabe M, Zhang G, Xia D, Gottesman MM (2010) Elevated expression of TMEM205, a hypothetical membrane protein, is associated with cisplatin resistance. J Cell Physiol 225:822-828

Timar J (2014) The clinical relevance of KRAS gene mutation in nonsmall-cell lung cancer. Curr Opin Oncol 26:138-144

Ulivi P, Delmonte A, Chiadini E, Calistri D, Papi M, Mariotti M, Verlicchi A, Ragazzini A, Capelli L, Gamboni A, Puccetti M, Dubini A, Burgio MA, Casanova C, Crinò L, Amadori D, Dazzi C (2014) Gene mutation analysis in EGFR wild type NSCLC responsive to erlotinib: are there features to guide patient selection? Int J Mol Sci 16:747-757

Wang L, Liu J, Liu J, Chen X, Chang M, Li J, Zhou J, Bai C, Song Y (2019) GLRX inhibition enhances the effects of geftinib in EGFRTKI-resistant NSCLC cells through FoxM1 signaling pathway. J Cancer Res Clin Oncol 145:861-872

Yu H, Su J, Xu Y, Kang J, Li H, Zhang L, Yi H, Xiang X, Liu F, Sun L (2011) p62/SQSTM1 involved in cisplatin resistance in human ovarian cancer cells by clearing ubiquitinated proteins. Eur J Cancer 47:1585-1594

Zhang L, Li J, Hu J, Li D, Wang X, Zhang R, Zhang H, Shi M, Chen H (2017) Cigarette smoke extract induces EGFR-TKI resistance via promoting EGFR signaling pathwayand ROS generation in NSCLC cell lines. Lung Cancer 109:109-116

Zhao N, Zhang XC, Yan HH, Yang JJ, Wu YL (2014) Effificacy of epidermal growth factor receptor inhibitors versus chemotherapy as second-line treatment in advanced non-small-cell lung cancer with wild-type EGFR: a meta-analysis of randomized controlled clinical trials. Lung Cancer 85:66-73

Zhdanov AV, Aviello G, Knaus UG, Papkovsky DB (2017) Cellular ROS imaging with hydro-Cy3 dye is strongly influenced by mitochondrial membrane potential. Biochim Biophys Acta Gen Subj 1861:198-204

Publisher's Note Springer Nature remains neutral with regard to jurisdictional claims in published maps and institutional affiliations. 